\title{
THE DEATH OF ALEXANDER THE GREAT
}

\begin{abstract}
The circumstances of Alexander's death are reviewed. Since contemporary sources vary in their accounts of the reason for his death, they are briefly reviewed and assessed. The account of Alexander's final illness is then discussed as recorded in the King's Journal and the Liber de morte testamentumque Alexandri Magni. The theory that he was poisoned is rejected, as is the hypothesis that he drank himself to death. His final illness shows symptoms characteristic of malignant tertian malaria (Plasmodium falciparum), possibly precipitated by recent wounds, exhaustion and heavy drinking.
\end{abstract}

\section{INTRODUCTION}

Alexander, King of Macedonia, conqueror of the Persian empire, died in Babylon at sunset on the $10^{\text {th }}$ of June, $323 \mathrm{BC} .{ }^{1}$ He was not yet 33 years old, had been king for 12 years and 8 months and had shown himself to be fully deserving of the title "The Great". Educated by Aristotle, trained in warfare by his father Philip II, he invaded Asia at the age of 22 and defeated Darius III within 3 years. He never returned to Macedonia but commenced with the establishment of an Asian empire based on Hellenistic culture whilst incorporating the best elements of the Persians and other conquered nations. With few exceptions he was remarkably magnanimous towards his former enemies, performing acts of justice far in advance of his time. As Tarn (1948:I.124125) puts it:

This was probably the most important thing about him: he was a great dreamer. To be mystical and intensely practical, to dream greatly and to do greatly, is not given to many men; it is this combination which gives Alexander his place apart in history.

1 On the controversy about the exact date of Alexander's death, cf. Hamilton (1969:210). 


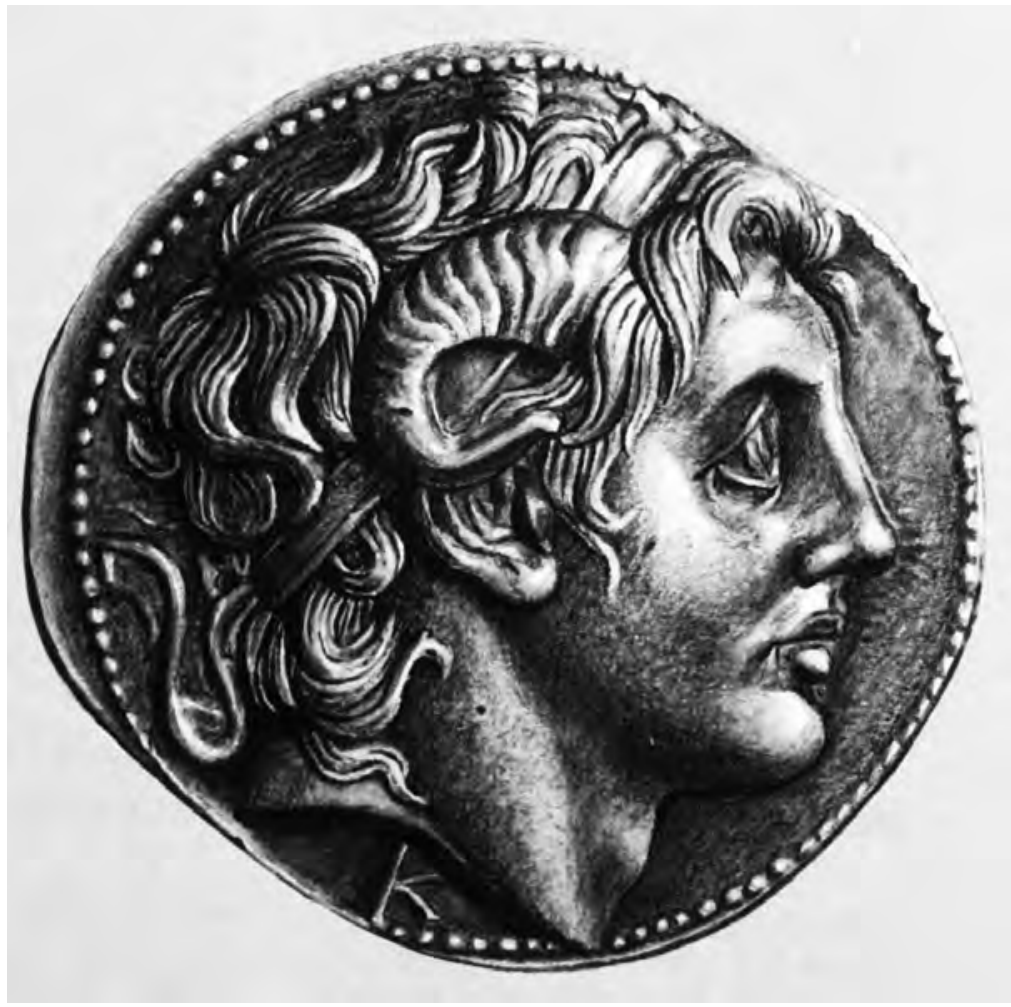

Figure 2: Silver coin from Thrace with the head of Alexander, portrayed wearing the horns of Zeus Amon, a god with both Eastern and Western ties.

Alexander's sudden death left his large and heterogeneous empire without a predetermined successor. This caused a protracted power struggle among his generals. Furthermore, the circumstances of his death soon became controversial — rumours of foul play and poisoning arose almost immediately, and were exploited by his contemporaries to further their own ends. The aim of this article is to review this historical event. 


\section{RELEVANT LITERARY SOURCES}

Our interpretation of the information about the last days and the death of Alexander will depend on the value we attach to the various ancient sources. Modern historians still vary in their assessment of these sources, which results in different views of the reasons for the death of Alexander. A brief overview of the ancient sources will be given.

\subsection{Contemporary sources}

Callisthenes was Aristotle's nephew, and an experienced writer appointed by Alexander to prepare a history of the Asian campaign. When he was executed in $327 \mathrm{BC}$ for complicity in a plot, his history covered the period up to $331 \mathrm{BC}$, and possibly even $329 \mathrm{BC}$. It is probable that his death lead to growing animosity between Alexander and his former tutor, Aristotle, as well as between the king and the Peripatetic School in Athens.

Ptolemy was one of Alexander's generals and later became King of Egypt in $304 \mathrm{BC}$. He published his History in the years 285-283 BC, making extensive use of the King's Journals, also known as the Royal Ephemerides. Although scholars have questioned the authenticity of this document ${ }^{2}$ it is accepted that Macedonian kings at least from the time of Philip II kept daily records of state. ${ }^{3}$ Responsible secretaries, of whom Eumenes was best known, travelled with Alexander, and if everything went according to plan, the records would after his death have accompanied his body back to Pella (the capitol of Macedonia) or Aegae for burial in the cemetery of the Macedonian kings. ${ }^{4}$ We know, however, that after Alexander's body had been prepared by Egyptian and Mesopotamian embalmers, it was diverted to Egypt by Ptolemy on its way back to Macedonia, late in 322 or early 321 BC.

2 Cf. Samuel (1965:1-12) and Bosworth (1971:112-136).

3 Cf. Pearson (1954:434):

... there is certainly no reason to doubt that some kind of diary was kept, recording the events of each day, the king's conferences, the orders he issued, the reports he received, and so on.

Cf. too Tarn (1948:II.1 et passim) and Hammond (1983:5-6).

4 Hammond (1980:248). 
With it presumably went the King's Journals. ${ }^{5}$ Ptolemy was the only general (and one of very few historians) to have seen these documents after 322 BC.

Cleitarchus of Alexandria was an influential contemporary writer, but he did not accompany Alexander. He collected second-hand information which he published as dramatic and sensational (often fantastic) stories - at times very negatively disposed towards Alexander. These appeared as a total history of more than 12 books between 322 and $314 \mathrm{BC}$. He was widely read and quoted but held in low esteem by serious scholars. Cicero, for instance, remarked that he was a better orator than historian, and quite ready to lie if it made the story more lively (Brutus 11.42), and Quintilian called him "brilliantly ingenious but notoriously untrustworthy” (Institutiones X.1.74).

Aristobolus was a Greek engineer in Alexander's service. He deserves special mention because of his meticulous history, published between 305 and 290 BC. However, its emphasis was on scientific and geographical rather than on military matters.

Hieronymus was a follower of Eumenes and a dependable historian who had much influence on Diodorus.

The Alexander Romance is a body of literature which came into being over a considerable period. It is a highly romanticised work containing fables and obvious fiction about Alexander's life and exploits. ${ }^{6}$ However, it also contains much factual data. Cleitarchus's stories form part of this literature.

The Liber de morte testamentumque Alexandri Magni is a potentially very significant document which circulated after Alexander's death. It was written by one Holkias, possibly in $317 \mathrm{BC}$, and was included at a later stage in various versions of the Alexander Romance. This pamphlet which purports to record the true history of Alexander's death and his final testament, suggests that he was poisoned, and in the plot

5 Pausanias 1.6.3.

6 Cf. Hammond (1980:4).

7 Cf. Heckel (1988) for the full text (as it occurs in the so-called Metz Epitome and in Recension A of Pseudo-Callisthenes) and for a discussion of the date, purpose and authorship of this document. 
various influential personalities involved in the struggle for succession were implicated. It is dealt with in more detail below.

\subsection{Sources from the Roman era}

None of the contemporary sources discussed above have survived; they are known to us only by way of references in later authors. These historians, who lived some 400 years later during the late Roman Republic and early Empire, are the only extant sources for the life and times of Alexander.

Diodorus Siculus ( $1^{\text {st }}$ century BC) was a Greek historian who wrote a universal history, the Bibliothêkê, from mythological times to $60 \mathrm{BC}$. His main source is Cleitarchus, but he also quoted from Aristobulus, Hieronymus and from sources said to have originated from Greek mercenaries fighting for Darius III.

Quintus Curtius Rufus ( $1^{\text {st }} / 2^{\text {nd }}$ century AD) was a Roman rhetorician and historian who wrote a ten-book history of Alexander, the Historiae Alexandri. He relied very heavily on Cleitarchus; apart from this the exigencies of rhetoric determined the selection of his source material.

Plutarch (46-120 AD), the Greek biographer and moral philosopher, is known mainly for his Fifty parallel lives, written to exemplify virtue (or vice) in the careers of great men in Greek and Roman history. In this work Alexander is compared with Julius Caesar. Plutarch reported objectively from every source available, "from the best to the worst" (Tarn 1948:II.296).

Arrian (Lucius Flavius Arrianus, 95-180 AD) was a Greek historian, and one of the most distinguished writers of his day. His most famous work deals with the age of Alexander; the only extant part is the Anabasis of Alexander, a history of Alexander in seven books from his accession to his death, based on the King's Journals and Ptolemy's rendering of it, supplemented mainly by Aristobulus.

Justin (Marcus Junianus Justinus, $2^{\text {nd }}, 3^{\text {rd }}$ or $4^{\text {th }}$ century AD) was the author of a Latin epitome of the otherwise lost Philippic Histories of Pompeius Trogus, a less significant and less accurate contribution. 


\subsection{An assessment of the sources}

In his book, Three historians of Alexander the Great. The so-called Vulgate authors, Diodorus, Justin and Curtius (1983), Hammond set himself the task of assessing the value of each of the five main accounts of the life of Alexander which has survived (Arrian, Diodorus, Justin, Curtius and Plutarch). It very soon emerges, merely by looking at these authors' accounts of Alexander's last days, that two groups can be distinguished (Hammond 1983:4-5). On the one hand there are Arrian and Plutarch: Arrian in his rendering of the final illness of Alexander, abbreviates and paraphrases the relevant passage in the King's Journals, and at the end remarks that "the accounts of Ptolemy and Aristobulus were not far from this [account]" (Anabasis 7.26.3); Plutarch's account (Alexander 76-77.1) is so similar to Arrian's that there is little doubt that each was drawing independently on the same passage in the King's Journals. On the other hand there are Diodorus, Justin and Curtius, whose accounts are totally incompatible with the first group. Which group is then to be regarded as correct? It largely depends on one's assessment of the authenticity of the King's Journals. Scholars like Samuel (1965), Hamilton (1969) and Bosworth (1971) maintain that the King's Journals was a forgery made in antiquity, and they therefore favour the latter group of authors. Hammond (1983:4-11), however, makes out a very convincing case for the authenticity of the King's Journals, and thus believes that Arrian and Plutarch are to be regarded as dependable.

Two contemporary sources in particular were hostile to Alexander and recorded a very negative image in many respects. The sensational stories of Cleitarchus still had a wide appeal, although he was not held in high regard by serious historians. And after the execution of

8 Cf. Hammond's scathing remark in this regard (1983:6):

It is, of course, an exciting idea that a modern scholar, operating only with paraphrased fragments, may be able to prove an ancient work to have been a forgery so ingeniously constructed that it deceived four ancient scholars (Plutarch, Arrian, Aelian VH 3.23, and Athenaeus 10.434b). But excitement is not enough; we need very strong arguments to support the idea.

He then convincingly refutes the arguments against the genuineness of the King's Journals. 
Callisthenes, Aristotle's nephew, the Peripatetic School in Athens proceeded to slander Alexander by inter alia picturing him as a debaucher and tyrant, and to attribute his achievements to luck and to the efforts of others. This view was still very popular in the Roman era, until Plutarch and Arrian, in particular, proposed a contrary view.

The account of Alexander's final illness as recorded by the two major sources, the King's Journals (preserved in inter alia Plutarch and Arrian) and the Liber de morte Alexandri Magni (in which the views of Cleitarchus and others are represented), will now be discussed. In an attempt to find the most likely reason for his death, information provided by these two sources will be evaluated carefully in the light of modern medical knowledge and circumstantial evidence such as the place where he died, the season and prevalent diseases at that time. It must be emphasised that absolute certainty cannot be reached in view of the inadequate medical descriptions given by historians more than 2000 years ago.

\section{LAST DAYS OF ALEXANDER}

\subsection{Previous medical history according to the sources}

Alexander was of less than average stature, well built, very fair with a tendency towards a ruddy complexion (Plutarch, Alexander 4.3). In battle he led by example and right through his career was extremely popular with his troops with whom he shared all hardships (Plutarch, Alexander 42.7-10 and Arrian, Anabasis 6.26.1-3). He was wounded often and seriously (Plutarch, Alexander 58.1). At Granicus (334 BC) his life was saved by Cleitus after serious injury (Plutarch, Alexander 16.11 and Arrian, Anabasis 16).

In his Parthian campaign (331 BC) he was hit in the lower leg by an arrow which so shattered the bone that bone-fragments had to be removed (Plutarch, Alexander 45.5 and Curtius Rufus, Historiae Alexandri 7.6.3). Plutarch also tells of an occasion when he suffered dimmed vision after a severe blow to the nape of the neck (Alexander 45.5 and Curtius, Historiae Alexandri 7.6.22). During the assault on Malli (India, $325 \mathrm{BC})$ an arrow pierced his breastplate and chest wall above the nipple, probably damaging the lung. The arrow was cut out with a 


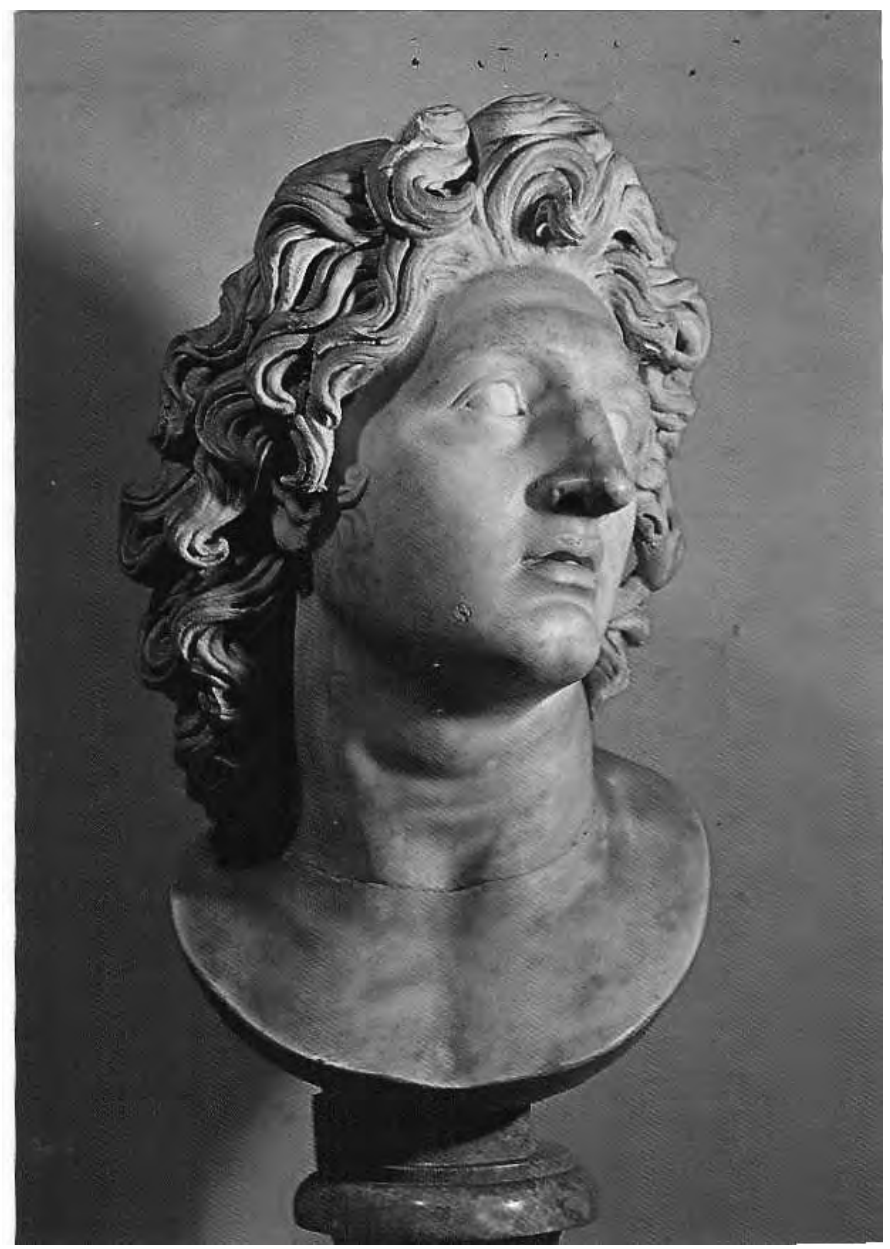

Figure 3: Alexander the great. Capitoline Museum, Rome.

sword, he bled profusely and fainted (Plutarch, Alexander 43.6-12 and Arrian, Anabasis 6.10-11). Tarn (1948:I.103) maintains that he never fully recovered from this incident and that his weakened state contributed to his ultimate death. 
Besides an attack of severe diarrhoea we know of only one other serious illness prior to the final incident. During his assault on Tarsus (333 BC) he fell dangerously ill with symptoms very similar to his final illness. According to Arrian he was eventually cured by a boyhood physician-friend, after he had lost his speech and become comatosed (Anabasis 2.4 and Plutarch, Alexander 19.4-10).

Cleitarchus and the Peripatetic School of Aristotle were mainly responsible for creating a negative image of Alexander as an alcoholic. ${ }^{9}$ It is probable that Alexander did drink heavily from time to time (like his fellow officers), and it is true that he murdered Cleitus (who saved his life at Granicus) in a drunken brawl (Plutarch, Alexander 50.151.11). But Alexander was no drunkard, and Plutarch's remark in this regard that the king let nothing hinder him when there was work to be done (Alexander 23.1-2), should be taken seriously. ${ }^{10}$

9 Hammond (1983:78). Ephippus of Olynthus too wrote a hostile pamphlet, On the end of Alexander and Hephaestion, in which he attributed Alexander's death to excessive drinking (Fragmente der griechischen Historiker $126 \mathrm{~F} 3$ ); this view is also found in Nicobulus (Fragmente der griechischen Historiker $127 \mathrm{~F} 1$ and F 2) and passed as truth into the Alexander Romance. This theory still has followers in modern times: Lane Fox (1975:467) refers to Alexander's last months as "a continuous record of carousing" and "Alexander's final month of debauchery”. Bosworth (1971:122) refers to this period as

a drinking marathon unique in history, in which the king spent his life alternately drinking himself to insensibility and sleeping off the results.

This view, which is based on certain passages in the King's Journals, was examined in detail by Hammond, who came to the conclusion that these passages refer to three dinner parties which Alexander attended within a period of a month at which he drank with his friends — "hardly an excessive programme for royalty" (1980: 298-9), and definitely not a justification for the views of Lane Fox and Bosworth.

10 Cf. too Plutarch (Moralia $337 \mathrm{f}$ and 623e) where he gives the view of Alexander's contemporary, Aristobulus, which has the same drift. Cf. further Arrian (Anabasis 7.29.4):

As for his reputed heavy drinking, Aristobulus declares that his drinking bouts were prolonged not for their own sake - for he was never, in fact, a heavy drinker — but simply because he enjoyed the companionship of his friends. 


\subsection{The final illness}

According to the King's Journals Alexander returned to Babylon in May 323 BC after journeying through the marshy Tigris-Euphrates delta. Within weeks he developed his final illness which lasted approximately 10 days. In summary, Arrian's description (Anabasis 7.25-27) is as follows:

After banqueting with friends far into the night during a time of general festivity for the whole army, he was invited to join in a carousal in honour of a god (probably Heracles) at the home of his close friend, Medius. After leaving the party, he bathed, slept most of the next day and then rejoined the festivities at Medius' home far into the next night. He then bathed, ate a snack and slept on the spot, because he had a fever. On waking up he was carried by stretcher to a sacrificial ceremony (a daily event in his life) after which he remained lying in the men's room till nightfall. During this time he was actively involved in issuing orders to commanding officers in preparation for a military operation (to Arabia) in five days' time. He was then carried by stretcher to the Euphrates river to sail and bath before resting. The next three days he became more feverish, but still made the customary daily sacrifices, bathed and discussed military operations. Very ill, he was then carried past his grief-stricken soldiers into the palace. Unable to speak he nevertheless still received his commanding officers. The fever continued unabated and two days later the army, fearing for his death, insisted on seeing him. As the soldiers filed past his bed, he was unable to speak to them but even so welcomed each of them, raising his head with difficulty and greeting them with his eyes. Some of his generals, keeping an all-night vigil in the shrine of Serapis, asked the god whether Alexander should be brought there. The god indicated that it was better for him to stay where he was. Shortly afterwards Alexander died.

The Liber de morte document also contains the details of the fateful dinner party at the house of Alexander's friend, Medius. It may be summarised as follows:

When Alexander invaded Asia he left the able but elderly Antipater in Macedonia to manage the European component of his domain and to look after the interests of his mother, the strong-willed and vindictive Olympias. She was displeased with Antipater's handling of affairs and continued to complain to her son. Eventually (324 BC) Alexander heeded her complaints and sent one of his best commanders, Craterus, with 10000 Macedonian veterans to replace Antipater. Expecting to be killed in the process, an alarmed Antipater plotted with Aristotle to assassinate Alexander, and sent his son, Cassander, to Babylon, ostensibly to argue his father's case, but in fact to murder Alexander. For this purpose an exceedingly powerful poison was 
prepared from the icy springwater near Nonakris in Arcadia - a poison so virulent that it destroyed metal, and had to be transported in a mule's hoof. In Babylon Cassander's brother Iolaos, cupbearer of Alexander, then poisoned his master at the banquet of Medius where most of the guests were party to the plot. On taking the poison Alexander felt a sharp pain in his back, cried out loudly and left the dinner. Excruciating pain now set in and Alexander died slowly in the course of five days, during which time Iolaos succeeded in administering further doses of the poison. In his agony Alexander attempted to drown himself in the Euphrates but was saved by his Bactrian wife, Roxana. Cassander then fled to Cilicia to await the arrival of Iolaos, and in the presence of loyal followers, Alexander composed his last will. He divided his empire among his generals and appointed Perdiccas as his successor and future husband for Roxana. As in the version of the King's Journals his mourning troops then filed past him before he died.

The salient point of this document is the accusation of murder levelled against the family of Antipater and identified collaborators at Medius's banquet. Heckel (1988) makes a convincing case that it was a cleverly prepared forgery designed to benefit certain persons in the complicated struggle for Alexander's succession, whilst attempting to eliminate others - and that it probably originated in 317 B.C. Cleitarchus (cf. Diodorus Siculus 17.118.1 and Curtius, Historiae Alexandri 10.10.14-19), Plutarch (Alexander 77.5) and Arrian (Anabasis 7.27) all knew of the poisoning theory but rejected it. Furthermore, Engels (1978:224-5) points out that it is most unlikely that Alexander, who was very swift in acting against conspiracies against his life — real or alleged — would allow himself to be slowly poisoned over five or more days, while placidly drawing up his testament. None of the alleged accomplices, or any one else for that matter, suffered any harm during the king's terminal illness. Recently Bosworth (1971:115-6 and 1346) also rejected the Liber de morte document, but hypothesised that Alexander might well have been assassinated by disgruntled followers, alarmed by his progressive megalomania and autocratic tendencies. He presents evidence of a junta being formed which then brought off a successful coup d'état aimed at establishing a balance of power among the plotting coalition members. This planned equilibrium subsisted for a year but was abruptly shattered by Perdiccas's bid for supremacy. 


\subsection{A medical perspective}

The theory that Alexander was poisoned has thus not yet been finally laid to rest, as is also evident from Milns's suggestion (1968:256-6) that strychnine was administered at Medius's banquet in unmixed wine — a procedure apparently recommended by Theophrastus. ${ }^{11}$ However, Engels (1978:224) points out that it is the non-lethal variety of strychnine which Theophrastus is referring to - the lethal variety was extremely bitter and would have been detected immediately. Furthermore the symptoms of strychnine poisoning are very obvious ${ }^{12}$ and are not substantiated by the symptoms recorded before Alexander's death (a violent intermittent fever, loss of voice and severe back pain). Neither do the symptoms of small doses of poison given over a period of time accord with those of Alexander. ${ }^{13}$

Similarly the hypothesis that Alexander actually drank himself to death, cannot be substantiated. The view that he was an alcoholic has already been refuted (cf. p.22 and notes 9 and 10), but Plutarch's report regarding his final illness merits further comment:

Aristobulus says that he had a raging fever, and that when he got thirsty, he drank wine, whereupon he became delirious, and died on the 30th day of the month Daesius (Moralia 337).

In Curtius (Historiae Alexandri 10.10.10-11) we read that in the hot plain of Babylon the water was not as pure as in the mountain springs of Macedonia; it is understandable that what Alexander drank daily was wine, not water. And when he became feverish, one can imagine that he quenched his thirst with wine. It is thus possible that Alexander's constitution was weakened by sporadic heavy drinking, and that it contributed towards his final illness.

The fact that Alexander's symptoms resemble those of malaria, was noted as early as 1872 by the French physician Emile Littré ${ }^{14}$ and has

11 Historia Plantarum 9.11.5-6, reference in Engels (1978:224 n.4).

12 “... muscular convulsions within fifteen to thirty minutes of ingestion, followed in a short time by unconsciouness and death" (Engels 1978:224).

13 “... subfebrile temperatures ... muscular rigidity, photophobia, hypersensitivity to noise, and lassitude" (Engels 1978:224).

14 Médicine et médicins (Paris 1872:406-415); reference in Engels (1978:225 n.8). 
recently been re-examined by Engels (1978:224-228). The malarial parasite is known to have existed on earth since antiquity and malaria has been endemic to the eastern Mediterranean at least since the $6^{\text {th }}$ century BC (Grmek 1991:280). Alexander's final illness shows symptoms characteristic of malignant tertian malaria (Plasmodium falciparum infection): a violent intermittent fever, severe back pain, and progressive loss of consciousness leading to death (Woodruff 1974:49). His presence in the swampy Euphrates/Tigris delta immediately before the onset of the disease would be corroborative evidence. Malaria is known to have been common in those areas, particularly so in the summer months of June and July. Engels (1978:225) points out that Alexander's weakened condition due to recent wounds, exhaustion and possibly heavy drinking would have precipitated the infection. He probably died of the well known and deadly cerebral complications of falciparum malaria. Disease was indeed very common among Alexander's troops Engels (1978:227) quotes Arrian (Anabasis 5.27.6) in stating that more soldiers died of illness than in battle. Although Alexander's final illness could conceivably have been caused by other febrile illnesses of the time, Sallares (1991:271) claims that malaria was the commonest cause of fevers in antiquity, and the symptoms known to us would be compatible with this diagnosis.

It is indeed possible that this was at least Alexander's second attack of malaria (Engels 1978:225). When he entered Tarsus in Cilicia (a most virulent malarial location even in modern times) in September $333 \mathrm{BC}$, he became seriously ill with a febrile condition and symptoms very similar to those of his final illness, including loss of speech and unconsciousness. ${ }^{15}$ Recovery from severe cerebral malaria is rare, but he was then younger and probably physically fitter, which could have contributed to his survival — only to succumb to a re-infection almost exactly 10 years later.

15 Recorded by Plutarch (Alexander 19.1-9), Arrian (Anabasis 2.4.7-8) and Curtius (Historiae Alexandri 3.5.3-3.6.13). 


\section{REFERENCES}

\section{ARRIAN}

1983. Anabasis of Alexander (transl. P. A. Brunt). London: W. Heinemann. Loeb Classical Library Vol. II.

BADIAN E

1967. A king's notebooks. Harvard Studies of Classical Philology 72:183-204.

\section{Bosworth A B}

1971. The death of Alexander the Great: rumour and propaganda. Classical Quarterly 21:112-136.

\section{Cicero}

1939. Brutus Orator (transl. G. L. Hendrickson).London: W. Heinemann. Loeb Classical Library Vol. V.

\section{Curtius}

1946. History of Alexander (transl. J.C. Rolfe). London: W. Heinemann. Loeb Classical Library Vols. I and II.

\section{DiODORUS SICULUS}

1933. Library of history (transl. C.H. Oldfather). London: W. Heinemann. Loeb Classical Library Vol. I.

\section{ENGELS D}

1978. A note on Alexander's death. Classical Philology 73:224-228.

\section{GRMEK M D}

1991. Diseases in the ancient Greek world. Translated by M. and L. Muellner. Baltimore and London: The Johns Hopkins University Press.

\section{HAMilTon J R}

1969. Plutarch, Alexander. A commentary. Oxford: Clarendon Press.

\section{HAMMOND N G L}

1980. Alexander the Great: king, commander and statesman. London: Chatto \& Windus. 1983. Three historians of Alexander the Great. The so-called Vulgate authors, Diodorus, Justin and Curtius. Cambridge: Cambridge University Press.

\section{HECKEL W}

1988. The last days and testament of Alexander the Great: a prosopographic study. Historia 56:1-114.

\section{LANE FOX R}

1975. Alexander the Great. Omega books.

\section{MiLnS R D}

1968. Alexander the Great. London: Robert Hale. 
The death of Alexander the Great

\section{PEARSON L}

1954. The lost histories of Alexander the Great. Oxford: Blackwell.

\section{PLUTARCH}

1919. Parallel lives (transl. B. Perrin). London: William Heinemann. Loeb Classical Library Vol. VII.

\section{QUINTILIAN}

2002. The orator's education (transl. D.A. Russell). London: W. Heinemann. Loeb Classical Library Vol. IV.

\section{SALLARES R}

1991. The ecology of the ancient Greek world. New York: Cornell University Press.

SAMUEL A E

1965. Alexander's "Royal Journals”. Historia 14:1-12.

\section{TARN W W}

1948. Alexander the Great. Vols. 1 \& 2. Cambridge: Cambridge University Press.

\section{WOODRUFF A W}

1974. Medicine in the tropics. Edinburgh \& London: Churchill Livingstone. 